\title{
DURABILITY OF MATERIALS BASED ON A POLYMER-SILICATE MATRIX AND A LIGHTWEIGHT AGGREGATE EXPOSED TO AGGRESSIVE INFLUENCES COMBINED WITH HIGH TEMPERATURES
}

\author{
VZDRŽLJIVOST MATERIALOV NA OSNOVI IZ \\ POLIMER-SILIKATNIH MATRIC IN LAHKEGA DODATKA, \\ IZPOSTAVLJENIH AGRESIVNIM VPLIVOM V KOMBINACIJI Z \\ VISOKIMI TEMPERATURAMI
}

\author{
Tomáš Melichar, Jiří Bydžovský, Ámos Dufka \\ Brno University of Technology, Faculty of Civil Engineering, Veveř́ 331/95, 60200 Brno, Czech Republic \\ melichar.t@fce.vutbr.cz \\ Prejem rokopisa - received: 2016-07-15; sprejem za objavo - accepted for publication: 2017-03-16
}

doi:10.17222/mit.2016.190

\begin{abstract}
The paper presents the results and findings of the research focused on an examination of progressive degradation of newly developed composite materials. These materials consisted of a polymer-silicate matrix and a mix of fillers with a considerable proportion of a porous aggregate. The matrix also contained a larger amount of alternative raw materials, in particular hightemperature fly ash and blast furnace slag. Prepared mixes were tested after different periods of exposure to an aggressive environment - for $45 \mathrm{~d}$ and $90 \mathrm{~d}$ (50 and 100 cycles). First, after $45 \mathrm{~d}$ and $90 \mathrm{~d}$, reference materials (i.e., those not exposed to aggressive influences) were tested. In parallel, tests were carried out with materials exposed to a solution of chloride ions and subjected to cyclic freeze and thaw. The last mode of testing in this research included materials exposed to cyclic freeze and thaw, chloride-ion solution and the consequent thermal load of up to $1000{ }^{\circ} \mathrm{C}$. The level of degradation was evaluated by means of physico-mechanical, physico-chemical and microstructural test methods. It was found that the exposure to cyclic freeze and thaw, water and chloride ions has no considerable influence on the reduction of the thermal resistance of the developed mix designs of polymer-silicate-based composites.
\end{abstract}

Keywords: durability, porous aggregate, polymer-silicate matrix, long-term exposure, chloride ions, water, frost, fire, microstructure

Članek predstavlja rezultate in izsledke raziskave, osredotočene na preverjanje napredujočega slabšanja na novo razvitih kompozitnih materialov. Ti materiali so sestavljeni iz polimer-silikatnih matric in mešanice polnil z znatnim deležem poroznih agregatov. Matrica je vsebovala tudi večjo količino alternativnih surovih materialov, visokotemperaturni dimniški pepel in žlindro. Pripravljene mešanice so bile testirane po različnih časih izpostavljanja agresivnemu okolju - $45 \mathrm{~d}$ in $90 \mathrm{~d}$ (v 50 in 100 ciklih). Najprej so bili, po 45 d in 90 d, testirani referenčni materiali, tisti, ki niso bili izpostavljeni agresivnim vplivom. Vzporedno pa so bila izvedena testiranja materialov, ki so bili izpostavljeni raztopini kloridnih ionov ter nato ciklično zamrznjeni in nato staljeni. Zadnji način testiranja $v$ tej raziskavi je bilo izpostavljanje materialov cikličnemu zamrzovanju in taljenju, kloridni raztopini ionov in ter toplotni obremenitvi do $1000{ }^{\circ} \mathrm{C}$. Stopnja degradacije je bila ocenjena glede na fizikalno-mehanske, fizikalno-kemične in mikrostrukturne testne metode. Ugotovljeno je bilo, da izpostavljenost cikličnemu zamrzovanje in taljenju, vodi in kloridnim ionom, nima večjega vpliva na zmanjšanje termične odpornosti na razvite mešanice iz polimer-silikatnih kompozitov.

Ključne besede: vzdržljivost, porozne mešanice, polimer-silikatna osnova, daljše izpostavljanje, kloridni ioni, voda, led, ogenj, mikrostruktura

\section{INTRODUCTION}

Technical papers, stating results of the research focused on the problems of the resistance of silicate (cement) matrix based composites, focus mainly on an assessment of the influences of individual adverse factors and aggressive environments. Scientists do not focus on a synergic action of more than two types of adverse influences, one of which is extremely high temperature. Several factors are crucial for a gradual degradation of polymer-silicate composites exposed to chloride ions, frost and high temperature. The first of them is mechanical deterioration of the composite caused by freezethaw cycles together with the water containing chloride ions. A water solution with chlorides penetrates through the surface and subsequently deeper into the structure of a composite material with a capillary-porous system. Depending on the depth of the ingression of the mentioned solution, affected areas are damaged during the temperatures changes above and below zero. The depth of penetration depends on the components used, in particular, the material base of the matrix, the used additions, their activities and the structure of the aggregate.

This problem is solved, in considerable detail, by $\mathrm{J}$. G. Jang et al. ${ }^{1}$ Apart from the influence of individual factors, the authors also described a combination of aggressive $\mathrm{CO}_{2}$ and $\mathrm{Cl}^{-}$ions, and it was proved that when the two act in synergy, the penetration of $\mathrm{Cl}$ ions is 
increased. This implies that the testing of a synergic action of negative influences affecting a given material is quite important because it is impossible to give an exact prediction only on the basis of an evaluation of individual aggressive substances. M. Maes et al. $^{2}$ confirmed that a replacement of Portland cement with blast-furnace slag in amounts of $50 \%$ and $70 \%$ considerably increases the resistance to the actions of $\mathrm{Cl}^{-}$and $\mathrm{SO}_{4}^{-2}$. It is also interesting that increasing the contents of sulfates in a solution increases the attack of chlorides. On the other hand, the concentration of chlorides has no influence on the sulfate attack on the mortar with blast-furnace slag. Slag generally has good resistance to sulfate attack, which was proved by M. Maes et al. $^{2}$, inter alia, with negligible changes in the volume and expansion. This finding is quite important from the viewpoint of a positive influence of blast-furnace slag on the resistance of a cement matrix to extreme temperatures.

The presence of $\mathrm{Cl}^{-}$ions in silicates is also important for a possible formation of Friedel's salt $-3 \mathrm{CaO} \cdot \mathrm{Al}_{2} \mathrm{O}_{3}$. - $\mathrm{CaCl}_{2} \cdot 10 \mathrm{H}_{2} \mathrm{O}$. This chemical compound can develop from free $\mathrm{Cl}^{-}$ions, which bind to $\mathrm{C}_{3} \mathrm{~A}$ or $\mathrm{C}_{4} \mathrm{AF}$. However, the reaction of the mentioned components is considerably influenced by several factors. As A. Delagrave et al. $^{3}$ and D. Izquierdo et al. ${ }^{4}$, Q. Yuan ${ }^{5}$ and L. Tang ${ }^{6}$ state, concentration of chloride ions, type of cement, replacement of cement, temperature or water-cement ratio are important. According to F. P. Glasser et al. ${ }^{7}$, a penetration of chloride ions with the consequent formation of Friedel's salt can, inter alia, cause a gradual filling of the porous structure of a given composite, which eventually slows down the transportation of $\mathrm{Cl}^{-}$ ions. The filling of pores is critical particularly for the thermal resistance where a porous structure is an advantage. The thermal decomposition of Friedel's salt is also important, i.e., gases developed during the dissociation, components remaining as residua and their capability for a further reaction with water consequently lead to an increase in the volume.

Durability of mortars with blast-furnace slag as the filler is described by Santamaría-Vicario et al. ${ }^{8}$ The research focused on the influence of a combination of several adverse environments - frost with water, alternating between humid and dry environment, simulation of a marine environment or crystallization of salts and gaseous $\mathrm{SO}_{2}$. Based on the results and findings, the possibility of using slag as a replacement of the aggregate was confirmed. The development and research of mortars with blast-furnace slag resistant to fire up to a temperature of $900{ }^{\circ} \mathrm{C}$ is presented by S. Aydin 9 . The tests involving blast-furnace slag as a replacement of the binder included mortars containing up to $80 \%$ of the slag. Pumice was used as the filler. Mortars with $40 \%$ of the slag showed the best test results. The residual compressive strength of these mortars exposed to $900{ }^{\circ} \mathrm{C}$ was $44 \%$, after they were gradually cooled down. After rapid cooling with water, the residual compressive strength of the mortar was around $40 \%$. The replacement of a fine aggregate with industrial by-products is a part of the research described by I. Yüksel et al. ${ }^{10}$ The amount of the substitution was from 10-50\%, with the subsequent thermal load of up to $800{ }^{\circ} \mathrm{C}$ at the age of $90 \mathrm{~d}$. A positive influence of the replacement of the commonly used dense aggregate with byproducts of the energy and foundry industry was unambiguously proved. The bottom ash showed the best results. One of the few publications, in which the authors provide the results of a research focused on the synergic action of high temperature and adverse environment (in particular $\mathrm{CO}_{2}$ ), was published by $\mathrm{G}$. Yuan and Q. $\mathrm{Li}^{11}$. The authors focus on the problems of concrete with various water-cement ratios exposed to temperatures of up to 700 ${ }^{\circ} \mathrm{C}$. One of the subsequent testing methods was the exposure to an environment with a higher concentration of $\mathrm{CO}_{2}$. The aim of the research presented by $\mathrm{G}$. Yuan and $\mathrm{Q}$. $\mathrm{Li}^{11}$ was the verification of the influence of a possible surface treatment of the tested concrete after its exposure to heat. The results show that as the exposure temperature grows, the resistance to carbonization decreases.

\section{METHODOLOGY OF EXPERIMENTAL WORK}

As the aim of the research was to design a material resistant to adverse environmental influences and possible fire at the same time, the selected matrix contained an increased amount of blast-furnace slag and high-temperature fly ash. Fly ash as a substitution binder increasing the thermal resistance was researched by $\mathrm{A}$. Nadeem et al. ${ }^{12}$ Microsilica was used as a supporting addition and stabilizing component; its positive effect in cement-based composites on the resistance to high temperatures was proven, for example, by T. Harun and C. Ahmet. ${ }^{13}$ Two types of aggregate were used. The coarser fraction of 1-2 $\mathrm{mm}$ was amphibolite, which is mined as a primary raw material. The fine-grained residue from washing the aggregate, produced as a by-product of adjusting the granulometric composition of the mined amphibolite, was used. The remaining part - a fine fraction of 0-1 mm - was fly-ash agloporite; the dominant part of agloporite is an energy-industry by-product - fly ash. As agloporite is created, through a self-burning process, from alternative raw-material resources, it can be characterized as an advantageous and cheap raw material, which is relatively environmentally friendly. The suitability of agloporite as a filler for materials with an assumed thermal resistance can be presumed, for example, on the basis of the results stated by V. Černý and Š. Keprdová. ${ }^{14}$ Mix designs of tested composite materials are listed in Table 1. Agloporite was saturated with water before its application in the mix. This fact was taken into account when correcting the water-cement ratio, which was adjusted to achieve good 
T. MELICHAR et al.: DURABILITY OF MATERIALS BASED ON A POLYMER-SILICATE MATRIX ...

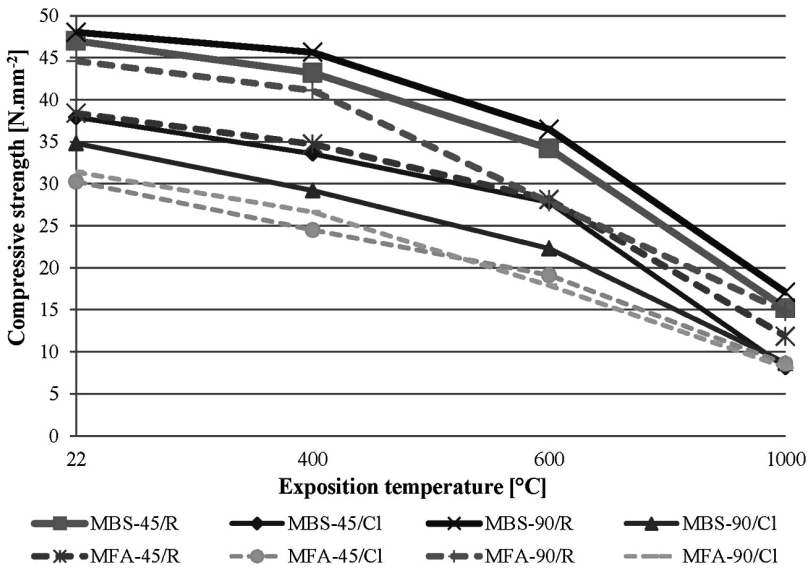

Figure 1: Compressive strengths of mixtures MBS and MFA after 45 $\mathrm{d}$ and $90 \mathrm{~d}(\mathrm{R}$ - temperature exposure; $\mathrm{Cl}$ - combination of chloride ions, frost and exposure to extreme temperatures)

Table 1: Composition of mixtures MBS and MFA

\begin{tabular}{|c|c|c|c|}
\hline Component & Unit & \multicolumn{2}{|c|}{ Mixture } \\
\hline & & MBS & MFA \\
\hline Cement & $\mathrm{kg} \mathrm{m}^{-3}$ & 443 & 443 \\
\hline Blast furnace slag & $\mathrm{kg} \mathrm{m}^{-3}$ & 251 & - \\
\hline Fly ash & $\mathrm{kg} \mathrm{m}^{-3}$ & - & 238 \\
\hline Vinyl acetate copolymer & $\%\left(\mathrm{w}_{\mathrm{C}+\mathrm{FBS}, \mathrm{FA}}\right)$ & 3 & 3 \\
\hline Microsillica & $\%\left(\mathrm{~W}_{\mathrm{C}+\mathrm{FBS}, \mathrm{FA}}\right)$ & 7 & 7 \\
\hline $\begin{array}{c}\text { Amphibolite (by-product) } \\
<0,063 \mathrm{~mm}\end{array}$ & $\mathrm{~kg} \mathrm{~m}^{-3}$ & 33 & 33 \\
\hline Porous aggregate 0-1 mm & $\mathrm{kg} \mathrm{m}^{-3}$ & 641 & 641 \\
\hline Amphibolite 1-2 mm & $\mathrm{kg} \mathrm{m}^{-3}$ & 792 & 792 \\
\hline Polypropylene fibres & $\mathrm{kg} \mathrm{m}^{-3}$ & 1.1 & 1.1 \\
\hline Water & $\mathrm{kg} \mathrm{m}^{-3}$ & 193 & 201 \\
\hline
\end{tabular}

workability of the fresh mix (a slump of around 160 $\mathrm{mm})$.

Out of each mix design, four sets of test specimens of $(40 \times 40 \times 160) \mathrm{mm}$ were made. The first and the second sets were treated in standardized conditions; then, after $28 \mathrm{~d}$ of maturing, the specimens were exposed to an adverse environment. In the adverse environment, the

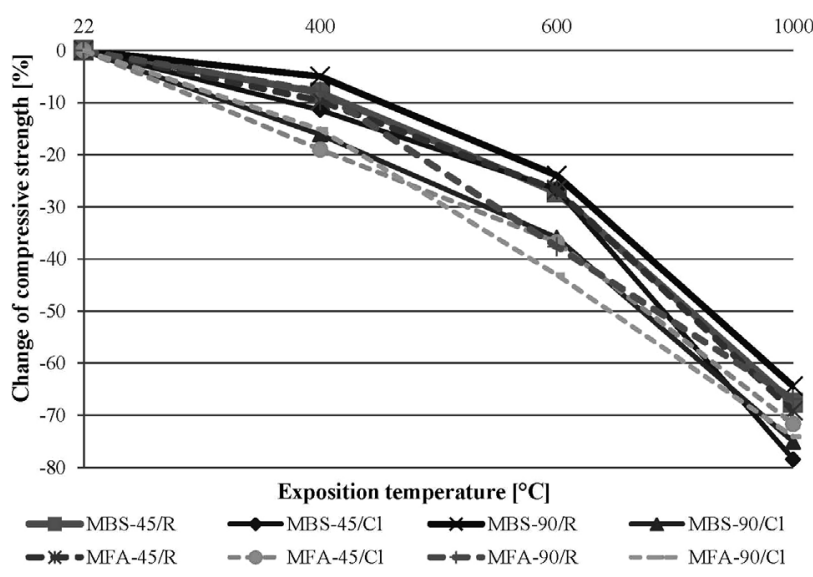

Figure 2: Percentage change of compressive strength due to chloride-ion solution and frost attack - weight change of mixtures MBS and MFA after $45 \mathrm{~d}$ and $90 \mathrm{~d}$

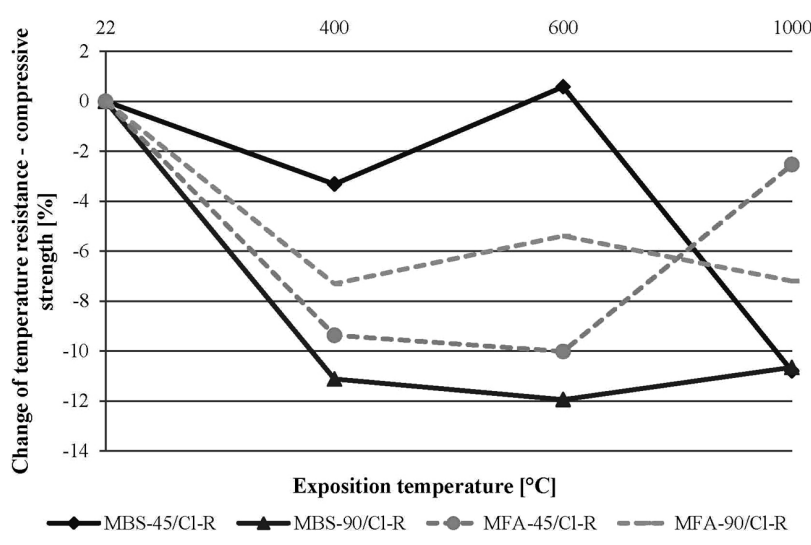

Figure 3: Change of temperature resistance (compressive strength) due to chloride-ion solution and frost attack - weight change of mixtures MBS and MFA after $45 \mathrm{~d}$ and $90 \mathrm{~d}$

temperature was cyclically changing (above and below zero), combined with a saturation of the solution with chloride ions (in accordance with ČSN $\mathrm{EN}^{17}$ ). After 50 cycles (and after $45 \mathrm{~d}$ elapsed from the standardized maturation), half of the specimens were subjected to tests of strength characteristics. The other half of the test specimens were exposed to temperatures of $(22,400$, 600 and 1000$){ }^{\circ} \mathrm{C}$. The rate of the temperature increase was around $10{ }^{\circ} \mathrm{C} \mathrm{min}-1$ with an isothermal dwell time of 90 min and slow cooling down. A similar procedure was also applied for the third and fourth set, where the test conditions were different regarding the number of cycles: 100 cycles were made in an adverse environment so that the specimens could be tested after $90 \mathrm{~d}$. It is important to emphasize that the testing was carried out after $45 \mathrm{~d}$ or $90 \mathrm{~d}$; however, the cycles were counted after the standardized age of $28 \mathrm{~d}$. The reason for this was the exposure of the test specimens to the adverse environment after the maturing process. The end of the cyclical exposure at the ages of $45 \mathrm{~d}$ or $90 \mathrm{~d}$ simulated the early age of a real structure.

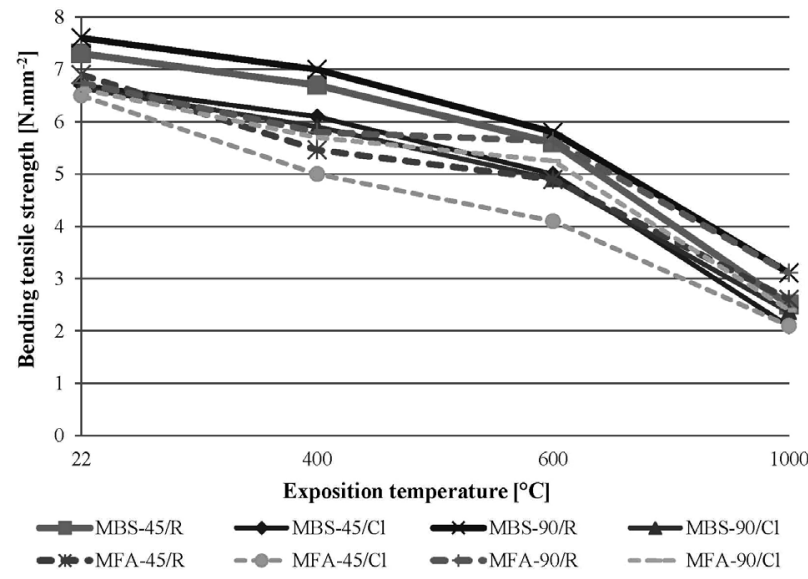

Figure 4: Bending tensile strengths of mixtures MBS and MFA after $45 \mathrm{~d}$ and $90 \mathrm{~d}$ ( $\mathrm{R}$ - temperature exposure; $\mathrm{Cl}$ - combination of chloride ions, frost and exposure to extreme temperatures) 
T. MELICHAR et al.: DURABILITY OF MATERIALS BASED ON A POLYMER-SILICATE MATRIX ...

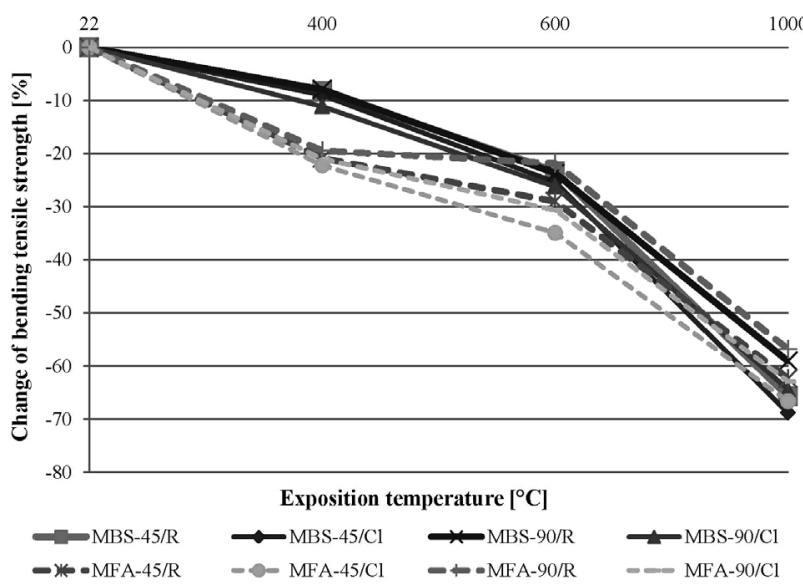

Figure 5: Percentage change of bending tensile strength due to chloride-ion solution and frost attack - weight change of mixtures MBS and MFA after $45 \mathrm{~d}$ and $90 \mathrm{~d}$

\section{RESULTS}

The diagrams below show the dependency of individual observed parameters on the exposure to aggressive environments and high temperatures, including their combination (Figures 1 to $\mathbf{6}$ ). The first compressive strength and tensile bending strength were examined. The first diagram of a given set - observed parameters (Figures 1 to 4) - shows the development of the abovementioned parameters in a given environment and at a given temperature (labeling: $\mathrm{R}$ - with no aggressive exposure, $\mathrm{Cl}$ - exposed to a solution of chlorides and frost). The second diagram of a given set shows the percentage changes of a particular parameter (Figures 2 and 5). The last diagram of a given parameter (Figures 3 and 6) shows the development of the temperature resistance (which is characterized by the percentage decrease of a given parameter). The curves presented as a solid line (dash line) denote mix designs MBS (MFA), i.e., the binder modified with blast-furnace slag (high-temperature fly ash).

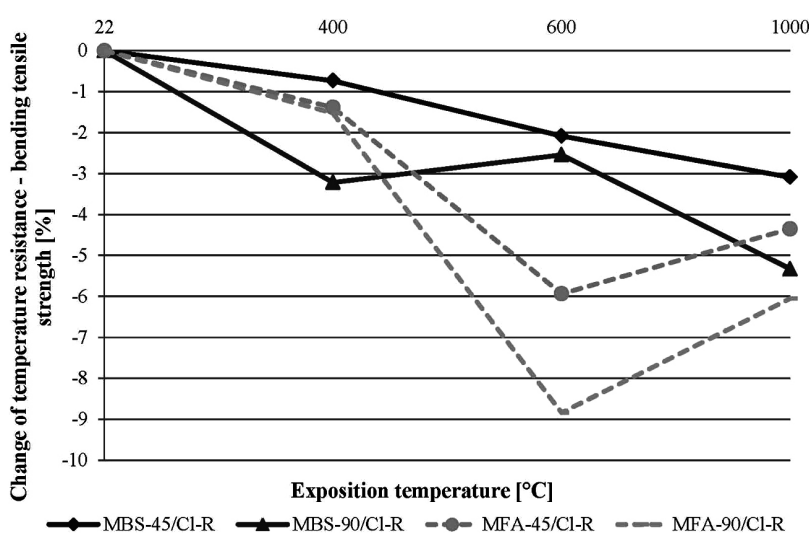

Figure 6: Change of temperature resistance (bending tensile strength) due to chloride-ion solution and frost attack - weight change of mixtures MBS and MFA after $45 \mathrm{~d}$ and $90 \mathrm{~d}$

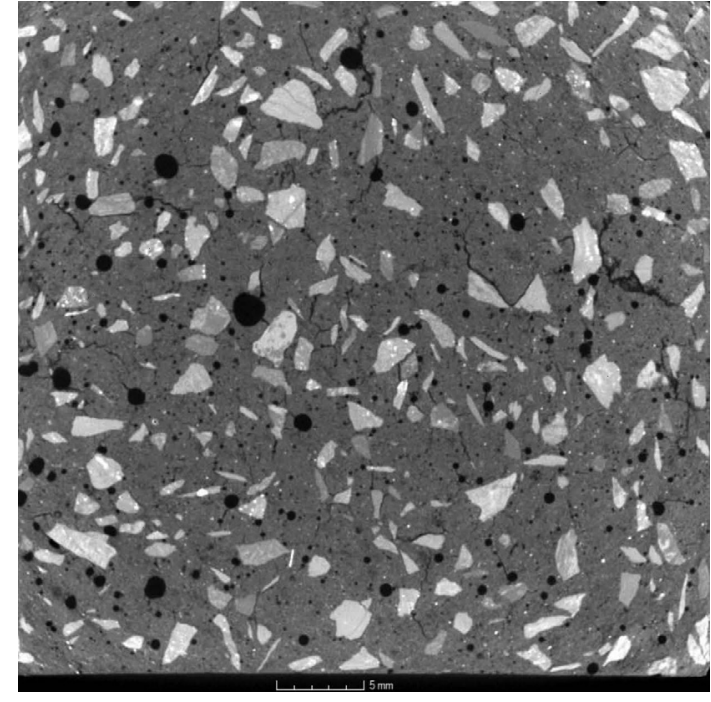

Figure 7: CT picture - slice of MBS-45/R (45 d, $R$ - reference sample without chloride solution and frost environment), exposure to $1000{ }^{\circ} \mathrm{C}$

Due to the chloride-ion solution and frost, failures are possible even inside the composite. The formation of cracks is the most likely failure. One of the key methods of the assessment of the structure of a material exposed to high temperatures is X-ray tomography (and CT). The CT examination focused on the presence of cracks, in particular, their number, width and orientation. It was important to determine where the cracks were found: the matrix, the aggregate or the transition zone. The location of cracks is also important: close to the surface or in the inner structure. Figures $\mathbf{7}$ to $\mathbf{1 0}$ show the test specimens exposed to adverse conditions. To identify and evaluate phase changes, an X-ray diffraction analysis was used (hereinafter referred to as XRD). The observed parameters were phase changes and the formation of new chemical compounds as products of the reaction of

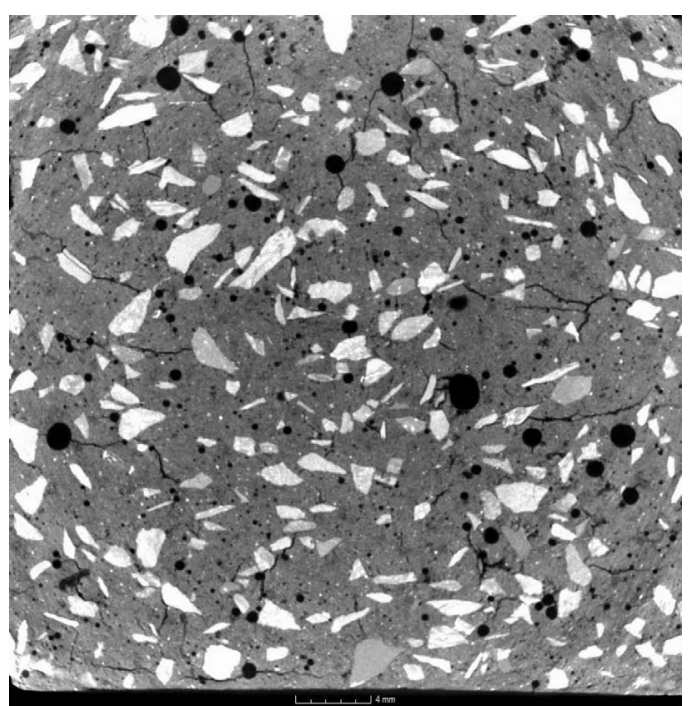

Figure 8: CT picture - slice of MBS- $45 / \mathrm{Cl}(45 \mathrm{~d}, \mathrm{Cl}$ - exposure to chloride solution and frost environment, 50 cycles), exposure to $1000{ }^{\circ} \mathrm{C}$ 
T. MELICHAR et al.: DURABILITY OF MATERIALS BASED ON A POLYMER-SILICATE MATRIX ...

chlorides with the matrix of a composite (Table 2). To make the picture complete, electron microscopy was used (hereinafter referred to as SEM). SEM focused on the formation of micro-cracks and the products related to the crystallization of chloride ions or their residua (Figures 11 and 12).

Table 2: XRD - mineralogical composition of mixtures MBS and MFA - selected samples

\begin{tabular}{|c|c|}
\hline \begin{tabular}{|c|} 
Mixture-age/ \\
environment, \\
temperature
\end{tabular} & Identified components \\
\hline $\begin{array}{l}\text { MBS-90/R, } \\
22\end{array}$ & $\begin{array}{l}\text { portlandite, calcite, } \beta \text {-quartz, ettringite, mullite, } \\
\text { chlorite, actinolite, anorthite, hematite, } \\
\text { akermanite, merwinite, gehlenite, CSH, } \\
\text { amorphous phase }\end{array}$ \\
\hline $\begin{array}{l}\text { MBS-90/R, } \\
1000\end{array}$ & $\begin{array}{l}\beta \text {-quartz, mullite, chlorite, actinolite, anorthite, } \\
\text { hematite, akermanite, merwinite, wolastonite, } \\
\text { amorphous phase }\end{array}$ \\
\hline $\begin{array}{l}\text { MBS-90/Cl, } \\
22\end{array}$ & $\begin{array}{l}\text { portlandite, calcite, } \beta \text {-quartz, ettringite, } \\
\text { mullite, chlorite, hematite, akermanite, } \\
\text { actinolite, wolastonite, gehlenite, biotite CSH, } \\
\text { amorphous phase }\end{array}$ \\
\hline $\begin{array}{l}\text { MBS-90/Cl, } \\
1000\end{array}$ & $\begin{array}{l}\beta \text {-quartz, mullite, actinolite, anorthite, hematite, } \\
\text { gehlenite, amorphous phase wolastonite }\end{array}$ \\
\hline $\begin{array}{l}\text { MFA-90/R, } \\
22\end{array}$ & $\begin{array}{l}\text { portlandite, calcite, } \beta \text {-quartz, ettringite, mullite, } \\
\text { chlorite, actinolite, anorthite, hematite, biotite } \\
\text { CSH, amorphous phase }\end{array}$ \\
\hline $\begin{array}{l}\text { MFA-90/R, } \\
1000\end{array}$ & $\begin{array}{l}\beta \text {-quartz, mullite, chlorite, actinolite, } \\
\text { amorphous phase, anorthite, hematite, } \\
\text { wolastonite }\end{array}$ \\
\hline $\begin{array}{l}\text { MFA-90/Cl, } \\
22\end{array}$ & $\begin{array}{l}\text { portlandite, ettringite, mullite, calcite, } \beta \text {-quartz, } \\
\text { anorthite, biotite, hematite CSH, amorphous } \\
\text { phase }\end{array}$ \\
\hline $\begin{array}{l}\text { MFA-90/Cl, } \\
1000\end{array}$ & $\begin{array}{l}\beta \text {-quartz, mullite, amorphous phase, anorthite, } \\
\text { hematite, wolastonite }\end{array}$ \\
\hline
\end{tabular}

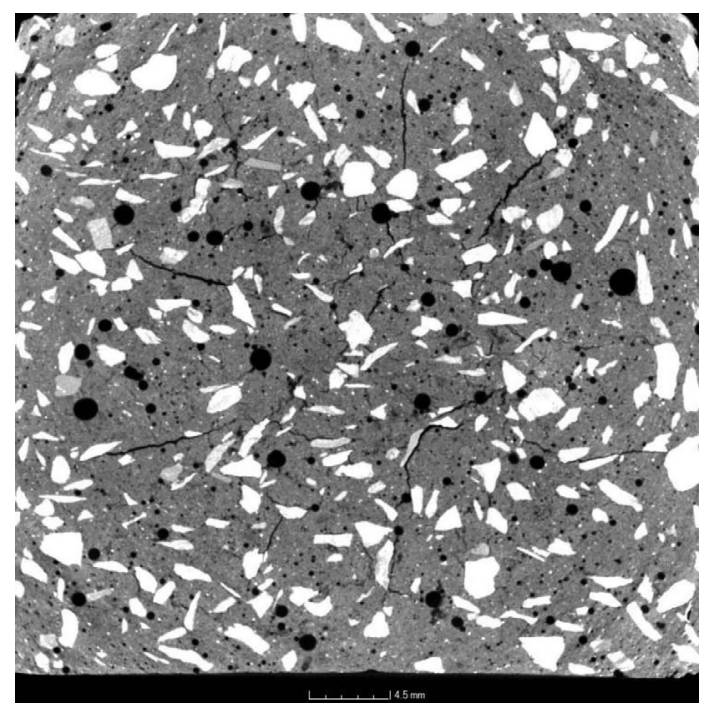

Figure 9: CT picture - slice of MBS-90/Cl (90 d, Cl - exposure to chloride solution and frost environment, 100 cycles), exposure to $1000{ }^{\circ} \mathrm{C}$

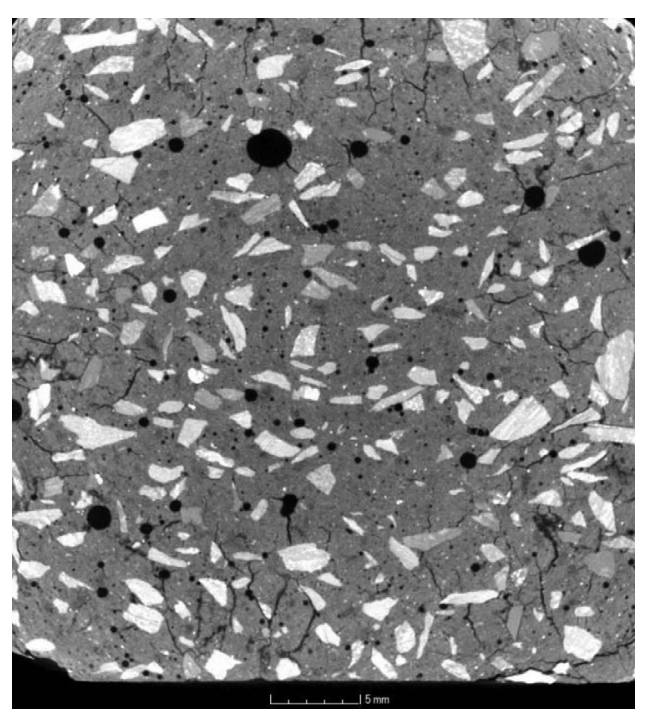

Figure 10: $\mathrm{CT}$ picture - slice of MFA- $90 / \mathrm{Cl}(90 \mathrm{~d}, \mathrm{Cl}$ - exposure to chloride solution and frost environment, 100 cycles), exposure to $1000{ }^{\circ} \mathrm{C}$

\section{DISCUSSION}

The diagrams (Figures 1 to 6) show the development of individual parameters and differences between the tested mix designs at a given age and exposed to a given environment.

Reference materials MBS-90 and MFA-90 showed compressive strengths of $48 \mathrm{~N} \mathrm{~mm}^{-2}$ and $45 \mathrm{~N} \mathrm{~mm}^{-2}$. As the diagram shows (Figure 1), the compressive strength decreases more considerably after an exposure to an aggressive environment. This fact is supported by the test results of the materials stored in laboratory conditions (in

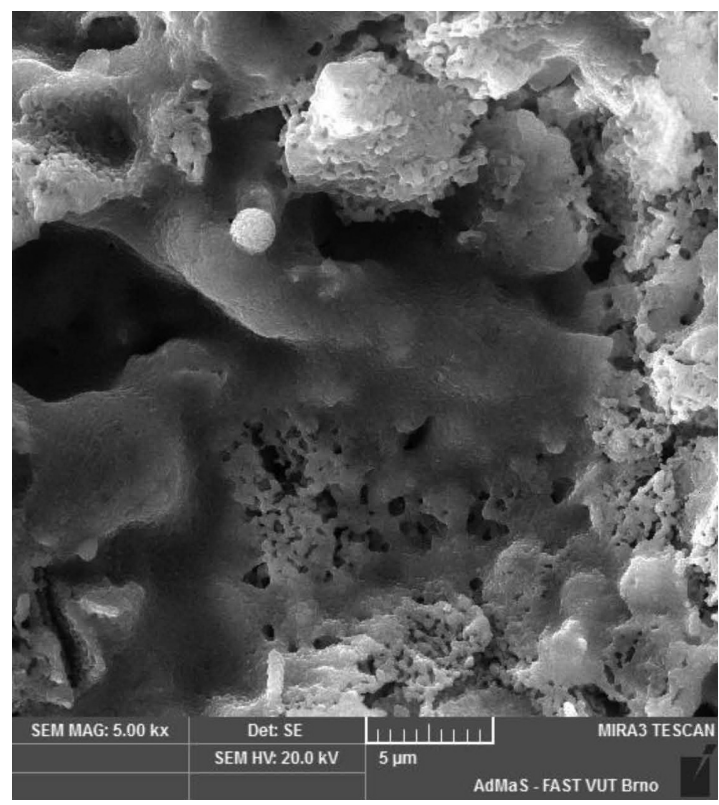

Figure 11: Microstructure of MBS-45/Cl (45 d, Cl - exposure to chloride solution and frost environment, 50 cycles), exposure to $1000{ }^{\circ} \mathrm{C}, 5000 \times$ magnification 
diagram "22"). A combination of frost and chloride ions caused a decrease in the strength of $27.5 \%$ (MBS-90Cl) and $29.6 \%$ (MFA-90Cl). These values can be assessed as adequate for the given type of material (i.e., the material with a porous aggregate) after a given number of cycles. The thermal resistance (a relative decrease in the compressive strength) of the materials in individual environments after being exposed to $1000{ }^{\circ} \mathrm{C}$ was approximately 64-69\% (72-78\%) for the reference samples (the samples exposed to the aggressive environment). It is interesting that slag (i.e., MBS) showed better results than the other reference material; however, after the exposure to the aggressive environment and high temperature, fly ash was better (i.e., MFA). For illustration, MBS-90/Cl (MFA-90/Cl) showed a decrease in the compressive strength of $75.1 \%$ (74.1\%; Figure 2). A slight increase in the thermal resistance developed over time in spite of the higher number of cycles in the aggressive environment. The only exception was MFA-90/Cl. An evaluation of the relative change in the thermal resistance caused by the aggressive environment shows an irregular development of the curves (Figure 3). This is particularly clear for temperatures of $600{ }^{\circ} \mathrm{C}$ and above. It is evident that the exposure to an aggressive environment and $1000{ }^{\circ} \mathrm{C}$ caused a decrease in the observed parameter of MBS (MFA) of approximately $11 \%(2.5-7.2 \%)$.

Further, the bending tensile strength was evaluated. The differences are less obvious compared to the development of the compressive strength (Figures $\mathbf{1}$ and 4). The increase in the bending strength in time was also less considerable than the increase in the compressive strength. The bending strengths of the test specimens not exposed to aggressive environments and a thermal load were from $7.3 \mathrm{~N} \mathrm{~mm}^{-2}$ to $7.6 \mathrm{~N} \mathrm{~mm}^{-2}\left(6.9 \mathrm{~N} \mathrm{~mm}^{-2}\right.$ to

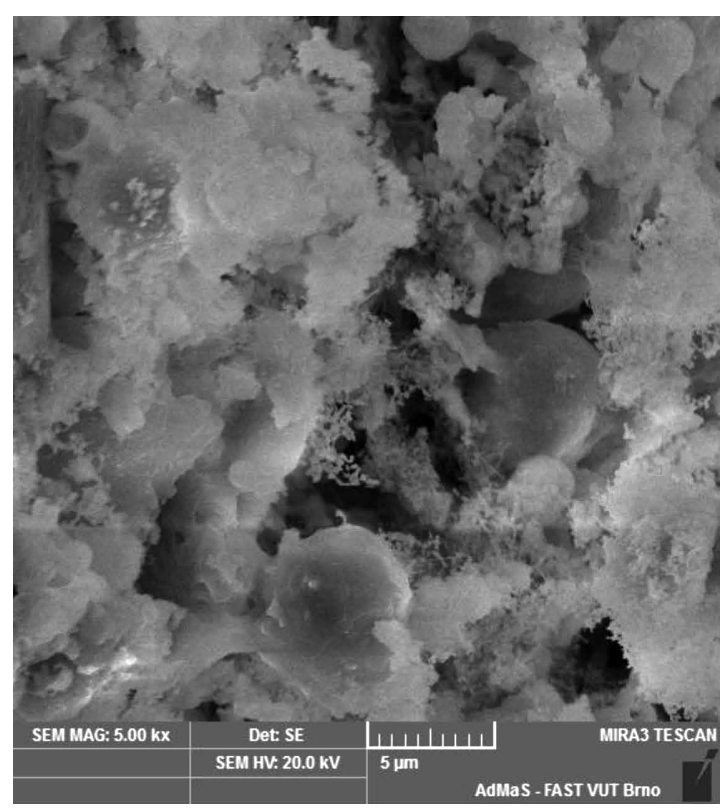

Figure 12: Microstructure of MBS-90/Cl (90 days, $\mathrm{Cl}-$ exposure to chloride solution and frost environment, 100 cycles), exposure to $1000{ }^{\circ} \mathrm{C}, 5000 \times$ magnification
7.2 $\mathrm{N} \mathrm{mm}^{-2}$ ) for mix designs MBS (MFA). After the exposure of the samples to the aggressive environment with chloride ions, the decrease was $12.6 \%$ for MBS-90 and $13.9 \%$ for MFA-90.

The decrease in the tensile bending strength caused by the exposure to aggressive environments is then much lower than that of the compressive strength. The negative impact on the thermal resistance was also smaller. The decrease in the tensile bending strength was $65.8 \%$ (62.3\%) for MBS-90/R (MFA-90/R) after the exposure to $1000{ }^{\circ} \mathrm{C}$ (Figure 5). These facts imply that the substitution of the primary binder with fly ash had a more positive effect from the viewpoint of a combined exposure involving an aggressive environment and a thermal load. On the other hand, comparing the changes in the thermal resistance in time and after the exposure to adverse environments shows (Figure 6) that blast-furnace slag had better results (MBS). The reduction in the thermal resistance after the exposure to $1000{ }^{\circ} \mathrm{C}$ was $5.3 \%$ for MBS-90/Cl-R and $6.1 \%$ for MFA/Cl-R. The reduction in the thermal resistance of MFA after the exposure to $600{ }^{\circ} \mathrm{C}$ is also interesting for both tested ages. It can be assumed that used high-temperature fly ash contains components that react with chloride solutions, possibly only during the thermal load. It could also be a synergy reaction of both mentioned influences.

The synergy effect of an aggressive environment and extreme temperatures causes a considerable degradation of the structures of the materials based on a silicate matrix and a porous aggregate. The given case is confirmed with the results of physico-mechanical tests of materials MBS and MFA. The CT examination proved the above character of the crack changes after the exposure to the aggressive environment (chlorides and frost) and the subsequent extreme thermal load. On the reference materials, only a small amount of randomly oriented cracks was identified (Figure 7). The cracks were rather small, i.e., with a smaller width. These cracks mostly did not reach the transition zone between the matrix and dense aggregate. On the contrary, the number of cracks of the materials exposed to the aggressive environment was larger (Figures 8 to 10). An increase in the width and number of the cracks is evident as the number of aggressive cycles and age of the samples grow. However, the increase was not considerable. The orientation of the cracks was easily observable; the cracks pointed towards the center of a test specimen (Figures 8 and 9). The width and number of the cracks and more cracks in the transit zone between the dense aggregate and the matrix were evident compared to the reference materials.

The last representative sample was FMA-60/Cl (Figure 10). It is interesting that its cracks are more close to the surface, with an orientation similar to that of MBS. Chloride ions combined with frost and the subsequent thermal shock damaged more considerably the surface areas of MFA, whereas MBS was damaged more evenly throughout the whole structure. 
The XRD analysis was used for the identification of crystal phases and their changes. XRD did not identify Friedel's salt in any of the tested specimens. The crucial factor of the formation of this chemical compound is the temperature, which is, inter alia, mentioned by Delagrave et al. ${ }^{3}$, Izquierdo et al. ${ }^{4}$, Yuan ${ }^{5}$ and Tang ${ }^{6}$. It is then evident that the damage of the structure caused by the combination of frost and the solution with chloride ions is purely mechanical. The salt in the solution $-\mathrm{NaCl}-$ is transported into the porous structure of the composite by equalizing the concentration gradient. Sudden changes of the temperatures above and below zero then cause the crystallization of the salt and the change of the phase of water, which necessarily causes a decrease in the mechanical properties of the given material. This corresponds with the findings determined with $\mathrm{CT}$. As regards the changes in the structures of the analyzed materials, a decomposition of chemical compounds (in particular mineralogical phases) typical for silicates and the used aggregate, due to the increasing temperature, was observed. The development shows peaks with a decreasing intensity and a gradual ceasing of portlandite, calcite and $\mathrm{CSH}$ phases. At temperatures over $600{ }^{\circ} \mathrm{C}$, mew phases were observed (like $\beta-C_{2} S$ ).

SEM together with an element analysis showed the presence of $\mathrm{Cl}^{-}$ions in some areas. Microcracks and the degree of decomposition of the hydration products of the matrix or the changes in the structure of the used aggregate were marked, as shown in Figures $\mathbf{1 1}$ and $\mathbf{1 2}$. Almost no failures were observable in the transit zone between the porous aggregate (agloporite) and the matrix. As regards the age of the tested materials/number of cycles, no considerable differences in the microstructure were observed. A 5000× magnification clearly shows a degraded polymer-silicate matrix. SEM images clearly show spherical particles of fly ash also in MBS. This was caused by an imperfect manufacturing process of agloporite, during which not all granules (for the production of the aggregate) were perfectly compacted and fired. However, as this fly ash had gone through the thermic process twice, it is almost an inert filler from the viewpoint of high temperature. Only few microscopic cracks were observed in the matrix.

\section{CONCLUSIONS}

The influence of a combination of an aggressive environment (chloride solution and freeze-thaw cycles) and a thermal load (of up to $1000{ }^{\circ} \mathrm{C}$ ) was tested and analyzed in detail on newly designed materials as it is not a thoroughly examined area. Fly-ash agloporite is a promising aggregate and its influence on polymer-silicate materials is still not quite clear. The advantage of agloporite is its thermal resistance and very good interaction with a polymer-silicate matrix. However, an exposure to cyclic changing of temperatures above and below zero, intensified by a salt solution, makes the use of the porous aggregate difficult. Blast-furnace slag (MBS) and fly ash (MFA) were used for a modification of the matrix composition. Physico-chemical and microstructural analyses proved that the action of the above-mentioned environment disturbs the structures of MBS and MFA in a mechanical way, causing an expansion due to the change of the phase of water or crystallization of salt rather than the formation of new chemical compounds. The extreme temperature then only intensifies these phenomena by degrading the structures, in particular that of the matrix. It was proved that CT is crucial for the explanation of the changes/failures of the inner structure. This analytical method is quite suitable for examining the three-dimensional structure of a given material. It is particularly applicable for revealing various cracks, their orientation, localization or number. The tested materials have a large potential for future research. An examination of the behavior of the materials over a longer time (e.g., $180 \mathrm{~d}$ and $360 \mathrm{~d}$ ) would also be very interesting.

\section{Acknowledgements}

This paper has been worked out with the financial support of The Czech Science Foundation (GAČR), project GA15-07657S, "Study of kinetics of processes occurring in the composite system at extreme temperatures and exposed to an aggressive environment", as well as under project No. LO1408 "AdMaS UP Advanced Materials, Structures and Technologies", supported by the Ministry of Education, Youth and Sports under the National Sustainability Programme I.

\section{REFERENCES}

${ }^{1}$ J. G. Jang, H. J. Kim, H. K. Kim, H. K. Lee, Resistance of coal bottom ash mortar against the coupled deterioration of carbonation and chloride penetration, Materials \& Design, 93 (2016), 160-167, doi:10.1016/j.matdes.2015.12.074

${ }^{2}$ M. Maes, N. De Belie, Resistance of concrete and mortar against combined attack of chloride and sodium sulphate, Cement and Concrete Composites, 53 (2014), 59-72, doi:10.1016/j.cemconcomp. 2014.06.013

${ }^{3}$ A. Delagrave, J. Marchand, J. P. Ollivier, S. Julien, K. Hazrati, Chloride binding capacity of various hydrated cement paste systems, Advanced Cement Based Materials, 6 (1997), 28-35, doi: 10.1016/S1065-7355(97)90003-1

${ }^{4}$ D. Izquierdo, C. Alonso, C. Andrade, M. Castellote, Potentiostatic determination of chloride threshold values for rebar depassivation experimental and statistical study, Electrochim. Acta, 49 (2004) 17-18, 2731-2739, doi:10.1016/j.electacta.2004.01.034

${ }^{5} \mathrm{Q}$. Yuan, Fundamental studies on test methods for the transport of chloride ions in cementitious materials, Doctoral Thesis, Ghent, Ghent University, 2009

${ }^{6} \mathrm{~L}$. Tang, Chloride transport in concrete-measurement and prediction, Doctoral Thesis, Göteborg, Chalmers University of Technology, 1996

${ }^{7}$ F. P. Glasser, J. Marchand, E. Samson, Durability of concrete degradation phenomena involving detrimental chemical reactions, Cem. Concr. Res, 38 (2007) 2, 226-246, doi:10.1016/j.cemconres. 2007.09.015

${ }^{8}$ I. Santamaría-Vicario, A. Rodríguez, C. Junco, S. Gutiérrez-González, V. Calderón, Durability behavior of steelmaking slag masonry mortars, Materials \& Design, 97 (2016), 307-315, doi:10.1016/ j.matdes.2016.02.080 


\section{MATERIALI IN TEHNOLOGIJE/MATERIALS AND TECHNOLOGY (1967-2017) - 50 LET/50 YEARS}

\section{T. MELICHAR et al.: DURABILITY OF MATERIALS BASED ON A POLYMER-SILICATE MATRIX ...}

${ }^{9} \mathrm{~S}$. Aydin, Development of a high-temperature-resistant mortar by using slag and pumice, Fire Safety Journal, 43 (2008), 610-617, doi:10.1016/j.firesaf.2008.02.001

${ }^{10}$ İ. Yüksel, R. Siddique, Ö. Özkan, Influence of high temperature on the properties of concretes made with industrial by-products as fine aggregate replacement, Construction and Building Materials, 25 (2011), 967-972, doi:10.1016/j.conbuildmat.2010.06.085

${ }^{11} \mathrm{G}$. Yuan, Q. Li, The use of surface coating in enhancing the mechanical properties and durability of concrete exposed to elevated temperature, Construction and Building Materials, 95 (2015), 375-383, doi:10.1016/j.conbuildmat.2015.07.120

${ }^{12}$ A. Nadeem, S. A. Memon, T. Yiu Lo, Mechanical performance, durability, qualitative and quantitative analysis of microstructure of fly ash and Metakaolin mortar at elevated temperatures, Construction and Building Materials, 38 (2013), 338-347, doi:10.1016/ j.conbuildmat.2012.08.042

${ }^{13}$ T. Harun, C. Ahmet, An experimental investigation of bond and compressive strength of concrete with mineral admixtures at high temperature, Arab. J. Sci. Eng., 33 (2008) 2B, 443-449
${ }^{14}$ V. Černý, Š. Keprdová, Usability of fly ashes from Czech Republic for sintered artificial aggregate, Advanced Materials Research, (2014), 805-808

${ }^{15}$ C SN EN 1504-3, Products and systems for the protection and repair of concrete structures - Definitions, requirements, quality control and evaluation of conformity - Part 3: Structural and non-structural repair, ČNI, 2006

${ }^{16}$ ČSN EN 1363-1, Fire resistance tests - Part 1: General requirements, ČNI, 2013

${ }^{17}$ ČSN 73 1326, including Z1, Resistance of cement concrete surface to water and defrosting chemicals, ČNI, 2003

${ }^{18}$ ČSN EN 12190, Products and systems for the protection and repair of concrete structures - Test methods - Determination of compressive strength of repair mortar, ČNI, 1999

${ }^{19}$ ČSN EN 196-1, Methods of testing cement - Part 1: Determination of strength, С̆NI, 2005 